Arkadiusz MODRZEJEWSKI

Uniwersytet Gdański

\title{
O europejskiej tożsamości Ukrainy w doktrynie Jana Pawła II
}

Na dorobek intelektualny papieża Jana Pawła II składa się kilkanaście stów pasterskich; ponadto książki wydane już za pontyfikatu (Przekroczyć próg nadziei, Dar i Tajemnica, Pamięć $i$ tożsamość), a także pokaźny zbiór prac naukowych i publicystycznych opublikowanych przed 16 października 1978 r., czyli dniem wstąpienia na Tron Piotrowy. Dużo miejsca w swoich rozważaniach poświęcił Papież kwestiom tożsamości człowieka. Można by nawet stwierdzić, że poniekąd właśnie tożsamość osoby ludzkiej stała się zasadniczym przedmiotem jego dociekań. Jeszcze jako filozof, profesor Katolickiego Uniwersytetu Lubelskiego, noszącego dziś Jego imię, zajmował się przede wszystkim antropologią (filozofią człowieka), poszukując elementów konstytuujących być człowieka. Pod koniec życia wydał jedno ze swych najciekawszych dzieł - Pamięć i tożsamość, w której znaleźć można zarówno wątki biograficzne, jak i odniesienia do historii i kultury Europy, w tym także Europy Środkowo-Wschodniej.

Jan Paweł II znany był z dużej biegłości w poruszaniu się w zagadnieniach dotyczących Europy Wschodniej czy dialogu katolicyzmu z prawosławiem. Wynikało to w dużej mierze z jego biografii. Jako Słowianin wśród łacinników miał zupełnie inny, bardziej bezpośredni, ogląd tych kwestii niż Jego poprzednicy czy rzymscy kurialiści. Rozumiał skomplikowane relacje narodowościowe, wyznaniowe i kulturowe na tym obszarze. Dlatego dużo miejsca w swych rozważaniach im właśnie poświęcał. Swoją uwagę kierował też w stronę Ukrainy ${ }^{1}$. I to zdaje się z dwóch powodów: względów rodzinnych - jego matka miała korzenie ukraińskie oraz specyficznej roli, jaką odgrywała Ukraina w historii stosunków europejskich, a w tym relacji między Kościołem zachodnim i wschodnim. 2001.

Zob. W. Mokry, Papieskie posłania Jana Pawła II do Ukraińców, Kraków 
Ludzie Zachodu traktują często Europę Wschodnią jako „inną”, co znaczy zwykle „gorszą”, Europę, jeśli w ogóle obszar ten traktują jako część Starego Kontynentu. Stan ten ugruntowała „zimna wojna”, podczas której ,żelazna kurtyna” odgradzała tzw. „,wolny świat”, w którym dominowały wartości europejskiej kultury politycznej, od strefy wpływów Związku Radzieckiego, gdzie wprowadzano zasady bolszewizmu z kolektywizmem jako jedną z naczelnych. I chociaż od upadku „muru berlińskiego" minęło kilkanaście lat, stereotypy te są nadal żywe. Przybrały może nieco inną formę. Dziś obowiązującym kryterium podziału zdaje się być rzekoma granica cywilizacji, oddzielająca świat Zachodu, czyli innymi słowy cywilizację zachodnią od kręgu kultury bizantyńskiej czy też prawosławnej. Chociaż z pewnością dla wielu Zachodnioeuropejczyków, ale i nie tylko, ten drugi krąg kulturowy oznacza generalnie obszar postradziecki, nazywany nierzadko pogardliwie (?) Wschodem, granica ta jest „ruchoma”. W zależności, kto nią się posługuje, tam ona przebiega. Dla niektórych jest nią nadal rzeka Łaba, czyli miejsce, przez które przebiegała ,żelazna kurtyna”. Inni widzą ją na Odrze, oddzielającej świat germańsko-romański od słowiańskiego. Inni jeszcze utożsamiają granice Europy ze wschodnimi granicami Unii Europejskiej. Są i tacy, i oni zapewne stanowią większość, szczególnie wśród intelektualistów, dla których Europa kończy się tam, gdzie kończą się wpływy zachodniego chrześcijaństwa ${ }^{2}$. Tę koncepcję w ostatnich latach wypromował amerykański politolog Samuel P. Huntington, wieszczący totalne ,zderzenie cywilizacji”"

Jakie jest miejsce Ukrainy w tych ujęciach? Nie trzeba być biegłym w geografii politycznej, by stwierdzić, że poza Europą i jej cywilizacją. Chociaż sam Huntington twierdzi, że właśnie przez Ukrainę przebiega granica cywilizacji. Zachodnia Ukraina, gdzie przeważa ludność greckokatolicka przynależy cywilizacyjnie do Europy ${ }^{4}$, podczas gdy większość jej terytorium zamieszkiwana przez prawosławnych jest częścią świata bi-

2 Zob. A. Chodubski, Świat wartości europejskich, w: Nauka społeczna Kościoła, tradycja i kultura a Unia Europejska, pod red. T. Linknera, A. Modrzejewskiego, Pelplin 2004, s. 10-11.

3 Zob. S. P. Huntington, Zderzenie cywilizacji, Warszawa 1997.

4 W rzeczywistości Cerkiew greckokatolicka jest Kościołem wschodnim, obrządku bizantyńskiego, jedynie uznającym zwierzchność biskupa Rzymu, czyli papieża. Pod względem liturgicznym, dyscypliny i teologii należy do chrześcijaństwa wschodniego (zob. M. Łesiów, Rola kulturotwórcza ukraińskiej Cerkwi greckokatolickiej, Lublin 1999). 
zantyńskiego, a więc do Europy jako przestrzeni kulturowej nie przynależy, chociaż pod względem geograficznym stanowi jej część. Tezy Huntingtonowskie stały się bardzo nośne podczas wyborów prezydenckich na Ukrainie w 2004 r., kiedy wieszczono jej rozpad na dwie części: południowo-wschodnią (prorosyjska) i środkowo-zachodnią (proeuropejską), oczywiście zupełnie mijając się z rzeczywistością społeczną i wyznaniową ${ }^{5}$.

Inaczej widział te kwestie Jan Paweł II, który już w latach 70. ubiegłego wieku zarzucił reprezentantom zachodniej części Starego Kontynentu „skłonność do myślenia i mówienia o Europie w wymiarach wyłącznie «zachodnich»"6. Dla Niego oczywistą rzeczą było współistnienie w Europie dwóch tradycji: łacińskiej (zachodniej) i bizantyńskiej (wschodniej). Nie sprowadzał kultury europejskiej do tradycji łacińskiej, ale widział w niej integralną całość złożoną zarówno z elementów zachodnio-, jak wschodniochrześcijańskich. Europa w koncepcji Karola Wojtyły jest jednością, której bogactwem jest wielość kultur ją tworzących. I to w odniesieniu zarówno do wielkich tradycji europejskiego Wschodu i Zachodu, jak licznych kultur narodowych i etnicznych. Jej dzieje porównuje do wielkiej rzeki, ,,do której wpadają liczne dopływy, a różnorodność tradycji i kultur, które ją kształtują, jest jej wielkim bogactwem"?.

W rozważaniach na temat spuścizny kulturowej Europy Jan Paweł II często posługiwał się alegorią „dwóch płuc”. Nie trudno pojąć, że mowa jest o Wschodzie i Zachodzie jako dopełniających się elementach europejskości. „Europa bowiem - jak zauważał Papież - jako całość geograficzna, jest [...] owocem działalności dwóch nurtów tradycji chrześcijańskiej, na które nakładają się również dwie różne, lecz jednocześnie głęboko się

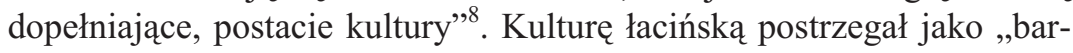
dziej logiczną i rozumową", podczas gdy tradycję wschodnią widział jako „bardziej mistyczną i uczuciową”. Dlatego nie sposób zrozumieć istoty

5 Zob. R. Drozd, A. Modrzejewski, Próby dezintegracji i reintegracji społeczeństwa ukraińskiego podczas wyborów prezydenckich 2004 roku, „Rocznik Wschodni” 2004, nr 10, s. 145-155.

${ }^{6}$ K. Wojtyła, Gdzie znajduje się granica Europy?, „Ethos” 1994, nr 28, s. 34. Po raz pierwszy artykuł ten opublikowano w 1978 r., jeszcze przed wyborem Wojtyły na papieża, we włoskim czasopiśmie „Vita e pensiero” (nr 61).

7 Jan Paweł II, Homilia wygłoszona podczas mszy świętej z okazji tysiqclecia męczeństwa św. Wojciecha na placu św. Wojciech w Gnieźnie 3 czerwca 1997 roku, w: Co Jan Pawet II mówi o zjednoczeniu Europy, Kraków 2003, s. 186.

8 Tenże, List apostolski ,Egregiae virtutis” z okazji ogłoszenia świętych Cyryla i Metodego wspótpatronami Europy, 31 grudnia 1980 roku, w: ibidem, s. 157. 
europejskości bez odwołania się do tych dwóch wielkich, uzupełniających się nawzajem tradycji kulturowych. Ich wzajemne relacje, ów organiczny i harmonijny związek, określił Papież jako niezaprzeczalny fenomen „,oskonałej jedności kontynentu"9. W opinii Papieża - Słowianina zanegowanie tej swoistej kulturowej symbiozy, czy jak sam nazwał „osmozy”, prowadzi do zanegowania Europy i europejskości jako takiej. Posługując się alegorią stwierdził, że bez któregokolwiek z ,płuc” Europa nie mogłaby po prostu oddychać ${ }^{10}$.

Fundamentem Europy, a zarazem jej czynnikiem konstytutywnym jest chrześcijaństwo jako takie (bez względu na tradycję ${ }^{11}$ ). Nie można, w opinii Papieża-Polaka, mówić o Europie bez odniesienia się do chrześcijaństwa, które stanowi jej conditio sine qua non. Jest ono „wspólnym mianownikiem” tożsamości wszystkich Europejczyków. Prawdziwą jedność Europy można uzyskać tylko wtedy, gdy powróci się do jej „korzeni”, a więc właśnie do chrześcijaństwa ${ }^{12}$. W myśli Karola Wojtyły zauważa się, że te wspólne chrześcijańskie korzenie całej Europy są trwalsze i żywotniejsze od jakichkolwiek podziałów na tradycję wschodnią i zachodnią ${ }^{13}$. Wpływy religii chrześcijańskiej, zarówno jej łacińskiej, jak i bizantyńskiej odmiany, wyznaczać będą tedy granice Starego Kontynentu. I chociaż sam Jan Paweł II często mówił o Europie jako o przestrzeni „od Atlantyku po Ural" - co było zapewne swego rodzaju demonstracją inkluzji wschodniego chrześcijaństwa, a zwłaszcza wschodniej Słowiańszczyzny, do wspólnoty europejskiej - to najistotniejszym czynnikiem decydującym o przynależności do tej kulturowej ekumeny była w jego wizji indywidu-

9 Tenże, Przemówienie skierowane do uczestników międzynarodowego dialogu nt. , Wspólne chrześcijańskie korzenie narodów europejskich”, 6 listopada 1981 roku, w: ibidem, s. 162.

10 Tenże, Przemówienie wygłoszone do kardynałów, rodziny dworu papieskiego, do kurii i do prałatury rzymskiej z okazji audiencji bożonarodzeniowej, 22 grudnia 1989 roku, w: ibidem, s. 192.

11 Papież implicite afirmował tezę brytyjskiego historyka Christophera Dawsona, który uważał, że fundamentami wielkich cywilizacji są wielkie religie (zob. Ch. Dawson, Religia i kultura, Warszawa 1958, s. 58). Nie zgadzał się natomiast z takim autorami, jak Feliks Koneczny czy przywoływany już S. Huntington, według którego na gruncie chrześcijaństwa (europejskiego) powstały dwie odrębne cywilizacje, tj. zachodnia (łacińska) i prawosławna, czyli bizantyńska (zob. S. Huntington, op. cit., s. 50 i passim; F. Koneczny, O wielości cywilizacyj, Kraków 1935).

12 Zob. S. Sowiński, R. Zenderowski, Europa droga Kościoła. Jan Pawet II o Europie i europejskości, Wrocław-Warszawa-Kraków 2003, s. 14-15.

13 W. Mokry, op. cit., s. 91-92. 
alna i zbiorowa (narodowa) kondycja ludzka. Co oznacza też, że ,granice Europy zasadniczo nie są dane raz na zawsze, ich kształt zamienia się w zależności od tego, czy dany naród i poszczególni jego członkowie zachowują swoje dziedzictwo duchowe. Poza tym - zauważa Papież - w minionych wiekach Europa na skutek podboju innych kontynentów niejako przekroczyła swoje geograficzne granice, co zrodziło i nadal rodzi określone konsekwencje kulturowe i polityczne"14.

Ukrainę zatem, podobnie jak cały świat tradycji bizantyńskiej, postrzegał Jan Paweł II jako część integralną Europy. Podczas pielgrzymki apostolskiej do tego kraju, którą odbył w czerwcu 2001 r., stwierdził wprost: „Ukraina ma oczywiste powołanie europejskie"15.

Jej europejskość związana jest z przyjęciem w 988 r. chrześcijaństwa w obrządku wschodnim. Papież jednak podkreślał, że w owym czasie istniała jedność wspólnoty chrześcijańskiej europejskiego Wschodu i Zachodu. Pomimo przyjęcia tradycji bizantyńskiej istniała więź między Rusią Kijowską a Rzymem jako centrum chrześcijańskiego świata. Oczywiście nie sposób tu w żadnym razie pomniejszyć roli Bizancjum. Jak zauważył Jan Paweł II: „Wiara chrześcijańska z miasta Rzymu przyszła na Ruś Kijowską przez miasto Konstantynopol. Stąd bierze się początek, stąd misjonarze katoliccy jako pierwsi przynieśli ze sobą Waszym ojcom ewangelię i jednocześnie oczyścili ich źródłem zbawiennej kąpieli. A jak wiemy, stało się to wtedy, kiedy Kościół Zachodni i Wschodni zachowywały swą jedność, i chociaż czerpał zewsząd, z dwóch różnych tradycji i należał do dwóch różnych kultur ludzkości, to tak naprawdę z tej jedności wypływały ogromne bogactwa Kościoła powszechnego" "16.

Chrzest Rusi Kijowskiej nie miał znaczenia tylko religijnego; nie był to tylko akt przyjęcia nowej wiary. Oznaczał też przyjęcie nowej kultury i nowego systemu wartości. Jest on źródłem tożsamości kulturowej Ukraińców, jak również Białorusinów i Rosjan, którzy w równym stopniu są spadkobiercami tradycji Księstwa Kijowskiego. Tradycja bizantyńska w opinii Papieża przyczyniła się też do zachowania pierwotnego, słowiańskiego dziedzictwa kulturowego. Była ona łatwiej przyswajalna przez ludy słowiańskie, zwłaszcza południowo- i wschodniosłowiańskie, gdyż

14 Ibidem, s. 17.

15 Jan Paweł II, Jesteśmy powołani, aby świadczyć o Chrystusie razem, 23 czerwca 2001 r. - Kijów. Ceremonia powitalna na lotnisku, nr 7, http://www.opoka.org.pl.

16 Tenże, List do Czcigodnego Kardynała Josyfa, Ukraińskiej Hierarchii Katolickiej i Narodu Ukraińskiego, nr 4, w: W. Mokry, op. cit., s. 183-185. 
od samego początku chrystianizacji Słowian przez Kościół konstantynopolitański, a to głównie za sprawą braci misjonarzy, świętych Cyryla i Metodego, korzystano w dziele ewangelizacji z dziedzictwa kulturowego tych narodów. ,Język i kultura słowiańska - zauważał Jan Paweł II stały się nowym kontekstem dla tego, co dotąd znajdowało swój wyraz bizantyński w stolicy Wschodniego Cesarstwa, a także na całym obszarze związanym z nim przez wieki. Do Słowian wschodnich Słowo Boże i łaska z nim związana dotarły w ujęciu geograficznie i kulturowo bliższym. Słowianie ci, przyjmując Słowo z całym posłuszeństwem wiary, pragnęli równocześnie wyrazić je zgodnie z własnym sposobem myślenia i we własnym języku. I tak dokonała się owa szczególna «inkulturacja słowiańska»" "17.

Karol Wojtyła bardzo mocno uwypuklał w tym względzie rolę Kościoła wschodniego, w którym wielką wartość stanowi dbałość o lokalne kultury, gdzie zwraca się szczególną uwagę na poszczególne ludy i ich specyfikę kulturową, ,aby słowo Boże i Jego chwała mogły rozbrzmiewać w każdym języku" ". Był zafascynowany postaciami świętych braci Sołuńskich, czyli Cyryla i Metodego, którzy jako pierwsi podjęli się trudu nawrócenia ludów słowiańskich na chrześcijańsko. 31 grudnia 1980 r. Jan Paweł II ogłosił ich współpatronami - obok św. Benedykta, twórcy zachodniego monastycyzmu - Europy. Poświęcił im też encyklikę Slavorum Apostoli ogłoszoną 2 czerwca 1985 r. Zauważył tam, że inaczej niż na Zachodzie, gdzie chrześcijaństwo „po okresie wędrówek ludów, stopiło przybyłe grupy etniczne z miejscową ludnością łacińską, rozciągając na wszystkich w celu ujednolicenia język, liturgię i kulturę łacińską, przekazywane przez Kościół Rzymu”, co prowadziło do sytuacji, w której „,każda odrębność była niekiedy odczuwana jako zagrożenie owej jedności in fieri”, a „wielka mogła być pokusa usuwania jej przy pomocy różnych form przymusu"19, na Wschodzie bracia Sołuńscy nie usiłowali narzucić ludom, którym głosili zasady wiary chrześcijańskiej, ani ,języka greckiego i kultury bizantyjskiej, ani zwyczajów czy sposobu postępowania społeczeństwa bardziej rozwiniętego, w którym wzrośli, i które siłą rze-

17 Tenże, List apostolski Euntes in Mundum z okazji Tysiqclecia Chrztu Rusi Kijowskiej, nr 3, w: ibidem, s. 261.

18 Tenże, List apostolski Orientale lumen do biskupów, do duchowieństwa i wiernych $w$ setnq rocznicę Listu apostolskiego Orientalium Dignitas Papieża Leona XIII, nr 7, w: ibidem, s. 364-365.

19 Tenże, Slavorum Apostoli, nr 12, w: http://www.opoka.org.pl 
czy musiały być im bliskie i drogie. Kierowani ideałem zjednoczenia w Chrystusie nowych wierzących dali językowi słowiańskiemu bogate, piękne teksty liturgii bizantyjskiej oraz dostosowali do umysłowości i obyczajów nowych ludów subtelne i złożone przepisy prawa grecko-rzymskiego" 20 .

I chociaż chrystianizacja Rusi Kijowskiej dokonała się sto lat po śmierci braci misjonarzy z Salonik, to właśnie oni mogą uchodzić za „ojców duchowych" tego dzieła. W ich duchu, przede wszystkim w duchu poszanowania lokalnych kultur, nastapił zwrot wschodnich Słowian ku chrześcijaństwu ${ }^{21}$.

W opinii Papieża przyjęcie chrztu przez Ruś Kijowską w obrządku wschodnim przy zachowaniu języka staro-cerkiewno-słowiańskiego dało początek długotrwałemu procesowi dziejowemu rozwijania i rozprzestrzeniania się oryginalnej bizantyńsko-słowiańskiej wersji duchowości i liturgii chrześcijańskiej. Ów specyficzny słowiański, czy raczej bizantyńsko-słowiański, ryt miał kolosalne znaczenia tak dla wschodniosłowiańskiej wspólnoty kościelnej, jak całych narodów wschodniej Słowiańszczyzny, które odnajdywały w nim przeszłości i nadal odnajdują źródło swej duchowej tożsamości ${ }^{22}$. Jan Paweł II jako człowiek „słowa”, zafascynowany „słowem”, zwracał szczególną uwagę na fenomen języka. Jako duchowny, filozof i teolog koncentrował się też na relacjach między słowem a światem nadprzyrodzonym, czy też jego symbolicznym wyrazie, jakimi są obrzędy liturgiczne. Z pewnością dlatego konstatował, że zachowując w liturgii bizantyńsko-słowiańskiej język słowiański dokonano jego nobilitacji. Stał się on przez to językiem literackim, ,a więc jednym z najważniejszych zjawisk i czynników kulturowych, które decydują o narodzie, jego identyczności i duchowej mocy"23.

W swoich rozważaniach o Rusi Kijowskiej i Ukrainie Jan Paweł II podkreślał, mając na uwadze tysiącletnią historię narodu ukraińskiego, znaczenie tego obszaru w relacjach między wschodnią a zachodnią Europą. Od swego zarania był on miejscem kontaktów przedstawicieli tych dwóch różnych tradycji europejskich. Dlatego w jednym z przemówień nazwał Ukrainę ,pograniczem i bramą między Wschodem i Zachodem”. To właśnie na ziemi ukraińskiej w ocenie Papieża doszło do „,skrzyżowa-

20 Ibidem, nr 13.

21 Zob. tenże, List apostolski Euntes in Mundum..., nr 3, s. 259-263.

22 Ibidem, nr 5, s. 267.

23 Ibidem, nr 6, s. 269. 
nia różnych kultur”, ,spotykały się duchowe bogactwa Wschodu i Zachodu"24. Jak nigdzie indziej „Kościół oddycha tutaj dwoma płucami tradycji wschodniej i zachodniej. Braterski dialog prowadzą tutaj ci, którzy czerpią ze źródeł duchowości bizantyjskiej, i ci, którzy karmią się duchowością łacińską. Głęboki klimat tajemnicy, dominujący w liturgii Kościołów Wschodu, i mistyczna zwięzłość rytu łacińskiego spotykają się tutaj i wzajemnie wzbogacają",25.

Karol Wojtyła zwracał szczególną uwagę na rolę Cerkwi greckokatolickiej w dialogu między Wschodem a Zachodem Europy. Jeszcze jako kardynał i metropolita krakowski podczas wizytacji parafii unickiej w Krakowie zauważył, że ta wspólnota kościelna wyrasta z idei zjednoczenia obu Kościołów, tj. wschodniego i zachodniego. Była w tym względzie prawdziwym pionierem ${ }^{26}$. Papież-Słowianin wskazywał na niewątpliwą wartość dwóch unii kościelnych: brzeskiej i użhorodzkiej. Oznaczały one zachowanie tożsamości wschodniochrześcijańskiej, czyli dziedzictwa liturgicznego i duchowego, odrębnej względem łacińskiej dyscypliny kościelnej i własnej hierarchii, przy jednoczesnym uznaniu prymatu biskupa Rzymu jako zwierzchnika całego Kościoła powszechnego ${ }^{27}$.

Jan Paweł II podkreślał rolę, jaką wschodnie Kościoły katolickie odgrywają w integracji europejskiej. Stan obecnego rozłamu we wspólnocie chrześcijańskiej uważał za wielce gorszący. Jego przezwyciężenie przyczynić ma się do intensyfikacji procesów zjednoczeniowych na Starym Kontynencie. Można odnieść nawet wrażenie, że ruch ekumeniczny był dla Papieża metodą osiagnnięcia pełnej i prawdziwej jedności Europy. Przykład udanego zjednoczenia stanowią właśnie wspólnoty katolickie obrządku bizantyńskiego. „Świadomy nieuniknionych trudności zachęcam wszystkich - głosił Jan Paweł II - do uznania i docenienia w duchu miłości i braterstwa wkładu, jaki moga wnieść w konkretne budowanie jedności katolickie Kościoły wschodnie przez samą swoją obecność, bogactwo tradycji, świadectwo «jedności

24 Jan Paweł II, Jesteśmy powołani, aby świadczyć..., nr 7.

25 Tenże, Budujcie jedność w różnorodności, 24 czerwca 2001 r. - Kijów, Spotkanie z biskupami katolickimi Ukrainy, nr 3, w: http://www.opoka.org.pl

${ }^{26}$ K. Wojtyła, Przemówienie podczas wizytacji parafii greckokatolickiej w kościele św. Katarzyny w Krakowie, 1-5 listopada 1972 r., w: W. Mokry, op. cit., s. 174-179 (tekst w języku polskim i ukraińskim).

27 Zob. Jan Paweł II, List apostolski na 400-lecie Unii Brzeskiej oraz tegoż, List apostolski na 350-lecie Unii Użhorodzkiej, w: W. Mokry, op. cit., s. 300-347. 
w różnorodności», inkulturację urzeczywistnianą w głoszeniu Ewangelii, różnorodność obrzędów"28.

Podsumowując należy stwierdzić, że to, co najważniejsze w refleksji Jana Pawła II, a wcześniej kard. Wojtyły, o Ukrainie czy szerzej o wschodniej Słowiańszczyźnie, to silne zaakcentowanie europejskiej tożsamości narodu ukraińskiego i w ogóle narodów wschodniosłowiańskich. Papież-Polak wskazywał, że od chrztu w 988 r. dzieje Rusi Kijowskiej i jej „duchowych” spadkobierców stanowią integralną część historii cywilizacji i kultury europejskiej. W ostatniej książce wydanej tuż przed śmiercią bez cienia wątpliwości, analizując proces ewangelizacji wschodnich Słowian, w tym dzisiejszych Ukraińców, skonstatował: „Wszystko to należy do dziejów Europy i ukazuje w jakiś sposób naturę samej europejskości,29.

\section{Summary}

John Paul II was renowned for his considerable competence in the issues of Eastern Europe and the dialogue between the Catholic and Orthodox faiths. To a large extent this followed from his biography. As a Slav among Latinists he had a completely different and much more direct outlook on those matters than his predecessors or Roman curial officers. He could understand the intricate relations between nations, denominations and cultures in this area. Therefore he devoted a considerable portion of his considerations to them. He also directed his attention to Ukraine. What was the most significant element in the reflection of John Paul II, former Cardinal Wojtyla, on the Ukraine, or - more broadly - on Eastern Slavs, was a strong emphasis on the European identity of Ukrainian nation and East-Slavic nations in general. The Polish Pope indicated that since its baptism in 988 the history of Kiev, Russia and its 'spiritual' inheritors form an integral part of the history of European civilization and culture. In his last book, published just before he died, the Pope analyzed the evangelization process of Eastern Slavs, including the present Ukrainians, and he stated without a shadow of doubt that "all that is a part of Europe's history and to some extent shows the European nature itself."

28 Jan Paweł II, Adhortacja apostolska Ecclesia in Europa, nr 32, Kraków 2003, s. 38-39. Zob. także ibidem, nr 119, s. 110.

${ }^{29}$ Tenże, Pamięć i tożsamość, Kraków 2005, s. 106. 